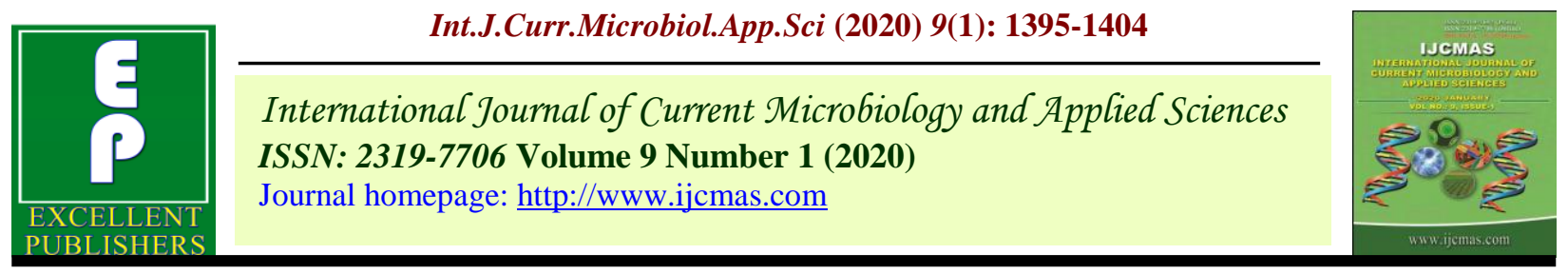

Original Research Article

https://doi.org/10.20546/ijcmas.2020.901.154

\title{
Socio-economic Condition of Khadia Poultry Farmers and Phenotypic Characteristics of Khadia Chickenof Northern Odisha, India
}

\author{
G. D. Nayak ${ }^{1}$, K. K. Sardar ${ }^{2}$ and B. C. Das ${ }^{3 *}$ \\ ${ }^{1}$ Department of Animal Breeding and Genetics, ${ }^{2}$ Pharmacology \& Toxicology, ${ }^{3}$ Veterinary \& \\ Animal Husbandry Extension, College of Veterinary Science and Animal Husbandry, \\ Odisha University of Agriculture \& Technology (OUAT), \\ Bhubaneswar-751003, Odisha, India \\ *Corresponding author
}

\begin{tabular}{|l|}
\hline Ke y w o r d s \\
Khadia, Socio- \\
economic, \\
Phenotypic, Tribal, \\
Native chicken
\end{tabular}

\section{A B S T R A C T}

The present study was undertaken to study thesocio-economic status of Khadia Chicken rearers along with phenotypic characteristics Khadia Chicken in two tribal districts of Northern Odisha. The sample size constituted two hundred households rearing 1435 Khadia chicken. The study revealed that $72.5 \%$ of the poultry rearers earned Rs.20,000 per year which is a substantial amount to support their livelihood. The qualitative characteristics like plumage colour, shank colour, skin colour, wattle type, comb type and fighting characteristics are quite distinct than the other native chicken of Odisha. The quantitative characteristics such as annual egg production, egg weight, fertility, body weight, mortality, shank length and keel length are different from the registered native breed of Odisha-Hansli. The results showed that annual egg production of Khadia native chicken averaged to $70.7 \pm 1.26$ and fertility was found $80.41 \pm 1.38 \%$. The male adult body weight was $1839.5 \pm 22.274 \mathrm{~g}$ and adult female weight $1388.75 \pm 10.96 \mathrm{~g}$. The shank length in male is $1.12 \pm 0.22 \mathrm{~cm}$ whereas the females shank length $9.78 \pm$ $0.24 \mathrm{~cm}$. These research-outcomes may serve as baseline information for the academicians, researchers and breeders for chalking out future breeding strategy for improvement of native chicken.

\section{Introduction}

India has 72.22 per cent of its population living in rural areas and 89 per cent rural livestock householder's rear native poultry as an important supplementary source of cash income (Khandait et al., 2011).Poultry production in India evolved from back yard venture to full-fledged poultry industry in last three decades (Reddy et al., 2015) Poultry plays an important role in human nutrition, national income, employment, and income generation in India. Meat and egg from native chicken is preferred by people because of its taste, leanness and pigmentation (Nigussie et al., 2015). Native chicken arebest known for 
their hardiness, adaptability to local agroclimatic condition, ability to utilize locally available feed, minimum requirement of care and management and less technology (Sharma, 2007; Moussa et al., 2018) that made farmers to rear native chicken in backyard and intensive on their own traditional methods. Native chicken are good scavengers and foragers, well adapted to harsh environmental conditions and their minimal space requirements make chicken rearing a suitable activity and an alternative income source for the rural Indian farmers. The indigenous fowl population also is considered asgene reservoirs particularly those genes that have adaptive values in tropical conditions (Horst, 1988). In addition, the local chicken sector constitutes a significant contribution to nutritional, food and livelihood security of India (ICAR-DPR, 2018-19).

Native chicken in India are found abundantly and distributed across different agro-ecologies under traditional scavenging management system indicating that they are important avian resources reared as a source of animal protein and income to many of the rural households (Fisseha et. al. 2010). Thus, their widespread distribution indicates their adaptive potential to the prevailing environment, disease and other stresses.

Mayurbhanj and Keonjhar districts in Northern Odisha are the major sources of biodiversity in poultry. Apart from crop production, native poultry rearing by tribal people in such tribal districts has become a chief source of their livelihood (Singh,et. al. 2016). Literature is not available on the socioeconomic conditions of Khadia chicken rearers and also its phenotypic characteristics. Therefore, investigation was carried out to generate base line information on Khadia chicken production systems, utilization, opportunities and challenges. The present paper is aimed at discussing the socio economic status of the farmers rearing native chicken and phenotypic characteristics of Khadia chicken.

\section{Materials and Methods}

\section{Sample size}

The present study was conducted in the purposively selected two districts of Northern Odisha viz. Mayurbhanj and Keonjhar as these districts are thickly populated with Khadia native chicken. Five blocks of Mayurbhanj district namely Baripada Sadar, Badasahi, Suliapada, Kuliana \& Samakhunta, and five blocks of Keonjhar district namely Keonjhar Sadar, Ghatagaon, Bansapala, Patna \& Harichandrapur were selected in consultation with local veterinarians. Therafter, from each block, two villages were selected randomly \& from each village ten poultry farmers were also sampled randomly for the study. Thus, two hundred households constituted the size of sample for socioeconomic study. Besides, 1435 native Khadia chicken were also studied to capture the phenotypic characteristics. Structured schedule was used for recording phenotypic characters of poultry maintained by the poultry farmers in the selected study areas.

\section{Study Area and Period}

The study was conducted in Northern Odisha in thickly populated poultry villages situated at the range of $12^{\circ} 15^{\prime} \mathrm{N}$ to $13^{\circ} 00^{\prime} \mathrm{Nand}$ $39^{\circ} 10^{\prime}$ Eto $39^{\circ} 50^{\prime}$. It has an altitude ranging from 930 to 3925 m.a.s.l. The mean annual temperature varies from $9{ }^{0} \mathrm{C}$ to $28{ }^{0} \mathrm{C}$. The coldest months are November, December and January with mean annual rainfall ranges from 400to $912 \mathrm{~mm}$ (SZT, 2012). The study was conducted to collect data from poultry farmers during the period from April 2018 to March' 2019. 


\section{Study design}

Questionnaire method and focal group discussions in native chicken production system were conducted in the two districts of Northen Odisha to capture qualitative as well as quantitative data. Group discussions were made at block level with group comprising 5 to 7 members (Bhuiyan et al., 2005).

Members of the focal groups include people having knowledge about past and present social and economic status of the area, community elders, women poultry keepers, veterinarians and extension personnel. Accordingly, data on chicken husbandry, health managements, opportunities and major constraints and/or challenges of village poultry production werealso collected.

\section{Statistical analysis}

Descriptive statistics such as mean, range, frequency and percentage were used to analyze the data using SPSS (2019). The Garrett ranking method was employed to rank the constraints faced by the poultry farmers in backyard poultry rearing system.

\section{Results and Discussion}

\section{Socio-Economic Benefits}

Native poultry meat is a cheap source of protein and household income particularly to the poor rural and peri-urban families in developing countries (FAO, 2003 and 2010).

The survey indicated that chicken farming is commonly practiced as a sideline activity, and none of the respondents specialized in this activity. However, benefits of chicken farming in the context of smallholder farmers were multi-faceted (Shahjahan and Bhuiyan, 2016)

\section{Household characteristics and respondents profile}

The analysis of data presented in table 1 reveals that majority (66\%) of the poultry farmers are of middle age group (35-45 years). This indicates that the native chicken rearing in the study area is probable supporting the household income. Very few respondents $(9.5 \%)$ were illiterate, whereas most of the farmers $(85.5 \%)$ were under the category of $7^{\text {th }}$ pass (Bhuiyan et al., 2005). Mostly, tribal farmers of the study area are opting job elsewhere who are $10^{\text {th }}$ pass or above qualification. Poultry rearing was done by $52.5 \%$ of the respondents who are landless farmers. This indicates that the poultry rearing is providing economic support to the landless farmers. Majority (57.5\%) of the poultry farmers was found having poultry birds of 20 to 50 numbers. This flock size may be suitable for the farmers to have a regular source of income (Fig.2). Income from poultry rearing is evident from the data that $72.5 \%$ of the poultry rearers get around Rs.20,000/- per year which is a substantial amount in the context of tribal economy (Saleque and Mustafa, 1996).

\section{Village Poultry Housing}

The survey indicated that all the farmers provided night shelter for their chickens in either part of in perch in veranda $(67.5 \%)$ or in separate housing $(32.5 \%)$ purposely made for chickens (). The poultry farmers of the study area used to make shelter arrangement in order to protect their birds from different types of predators. These findings are in line with Selam (2010), Sultana et al., (2012) and Eskinder (2013) who kept their poultry inside dwelling to protect them from jungle cats, foxes and thieves, but contradict with the reports of Halima, et. al. (2007) and Bogale (2008). 


\section{Incubation of egg}

The broody hens are used by tribal poultry rearers for incubation of eggs to hatch out the chicks (Fig.2). The number eggs set for incubation ranged from 10-16, and normally the Khadia female birds undergo brooding 2-3 times in a year. On the contrary, Tadelle (1996); Dereje (2001);Tadelle (2003) reported that traditionally households attempted to break broodiness to resume egg laying with the final goal of increasing egg productivity.

\section{Diseases and Health management}

Diseases were one of the major bottlenecks for village chicken productions in the study areas. Marek's disease, Ranikhet disease, fowl pox, coccidiosis, parasitic infestation and other respiratory diseases were the most common among the village chicken ofNorthern Odisha. During the interview and farmer group discussions (FGD), the major disease easily recognized by thevillagers was Ranikhet disease, fowl pox and parasitic infestation (Chaka, et al., 2012; Billah et al., 2013; Mulisa et al., 2014). Most of the time of the year, desirable characters namely, hardiness, adaptability to the wide agroclimatic variability ranging from tropical to subtropical climate, disease tolerance, and flavour of meat and eggs of native chicken germplasm protects them from several infection (Higenyi, et al., 2014; Terefe et al., 2015; Singh et al., 2017).

\section{Phenotypic Characteristics of Khadia Chicken}

Mayurbhanj and Keonjhar districts of Odisha are reservoir of poultry germ plasm. For last several generations, a tribal population named Khadia is inhabitating these areas with their own local birds which has undergone several generations of rearing, and the birds have a quite distinct features from other populations of that area. These birds with similar phenotypic characteristics are called as Balia birds in Keonjhar district.

\section{Qualitative Parameters}

Seven qualitative parameters of male and female birds considered for this study were: plumage colour, shank colour, skin colour, wattle type, comb type and fighting characteristics. Other visible specific traits such as well-developed spur in adult males having fairly long neck with plenty of hackle feathers. The beak is fairly long, pointed at tip and light yellow in colour while wings are large in size well folded (Hailemichael et al., 2015; Hareesh and Guru Vishnu, 2015). The plumage colour of this bird is black breasted red and birchen while the registered breed Hansli is mostly black and solid (Eskindir et al., 2013). The shank color of Khadia chicken is blackish yellow whereas it is yellow in case of Hansli. The skin colour is pink in hansli and on the other hand, it is white in Khadia. Wattles are well developed in Khadia but, rudimentary in Hansli. Again comb type is mostly single, but pea in Hansli. Khadia birds are reared by tribals for livelihood as well as for fighting purpose whereas Hansli is mostly used for fighting purpose (Nandi et al., 2017, Mohanta et al., 2018).

\section{Quantitative parameters}

Seven quantitative parameters were recorded for both male and female birds such as annual egg production, egg weight, fertility, body weight, mortality, shank length and keel length which are analyzed and presented in Table 2.The annual egg production of Khadia native chicken averaged to $70.7 \pm 1.26$ whereas the fertility is found to be very high $(80.41 \pm 1.38)$ which is in agreement with Haunshi et al., (2009) and Saleem et al., (2014). The male adult body weight (1839.5 \pm 22.274) was higher than adult female weight 
(1388.75 \pm 10.96$)$. The mortality of birds between 1 - 8 weeks of age was 6-9 \% whereas the mortality in 8-20 weeks age

Fig.1a Mayurbhanj District

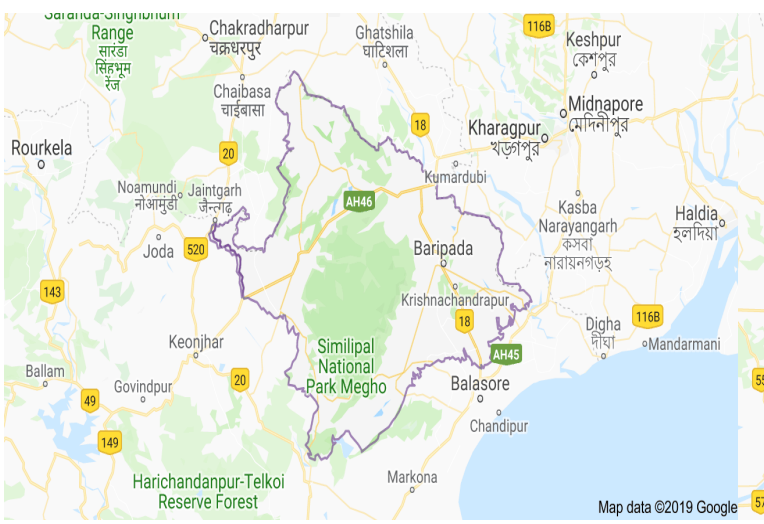

group was $5.47 \%$ which corroborates the findings of Nandi et al., (2017) and Mohanta, et al., (2018).

Fig.1b Keonjhar District

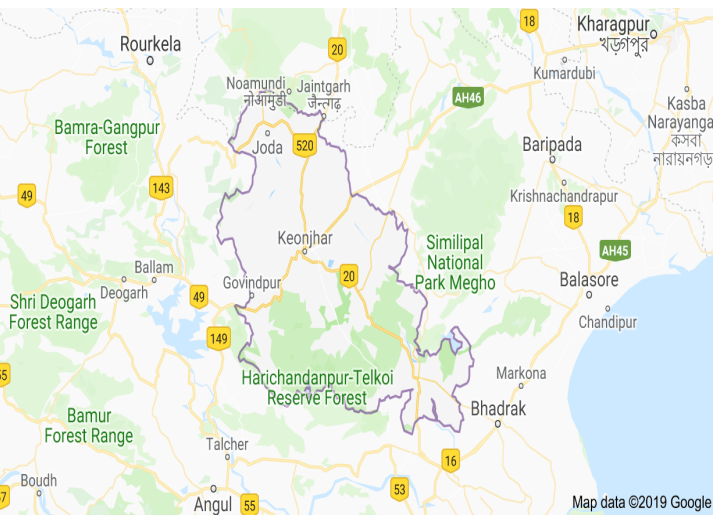

Table.1 Distribution of the Backyard Poultry Farmers as per their Socio-economic characteristics $(n=200)$

\begin{tabular}{|c|c|c|}
\hline Parameter & Classification & Percentage \\
\hline \multirow{3}{*}{ Age } & Young $(<30$ years) & 12.5 \\
\hline & Middle ( $30-45$ years) & 66.0 \\
\hline & Old ( $>45$ years $)$ & 21.5 \\
\hline \multirow[t]{3}{*}{ Education } & Illiterate & 9.5 \\
\hline & $7^{\text {th }}$ pass & 85.5 \\
\hline & $10^{\text {th }}$ and above & 5.0 \\
\hline \multirow[t]{3}{*}{ Land holding } & landless & 52.5 \\
\hline & Marginal & 40.5 \\
\hline & Small & 7.0 \\
\hline \multirow[t]{3}{*}{ No of birds } & $1-20$ & 26.0 \\
\hline & $21-50$ & 57.5 \\
\hline & 51 and above & 16.5 \\
\hline \multirow[t]{2}{*}{ No of livestock } & Large animals & 22.0 \\
\hline & Small animals & 78.0 \\
\hline \multirow[t]{3}{*}{ Annual Income from poultry } & (<Rs.20,000) & 77.5 \\
\hline & (Rs.20,000-50,000) & 18.5 \\
\hline & ( > Rs. 50,000 ) & 4.0 \\
\hline \multirow{2}{*}{ Type of House } & Katccha & 2.5 \\
\hline & Pucca & 97.5 \\
\hline \multirow[t]{3}{*}{ Type of main occupation } & Agriculture & 85.5 \\
\hline & Livestock Rearing & 12.5 \\
\hline & Others & 2.5 \\
\hline \multirow[t]{2}{*}{ Poultry Housing } & Perch in veranda & 67.5 \\
\hline & Separate hosing & 32.5 \\
\hline
\end{tabular}


Table.2 Phenotypic Characteristics of Native Khadia Chicken

\begin{tabular}{|l|c|c|c|}
\hline \multicolumn{1}{|c|}{ Parameters } & Average & Range & N \\
\hline Annual egg production & $\mathbf{7 0 . 7 \pm 1 . 2 6 4}$ & $\mathbf{5 5}$ to 95 & $\mathbf{4 0}$ \\
\hline Egg weight (g) & $40.38 \pm 0.58$ & $35-50$ & 40 \\
\hline Fertility (\%) & $80.41 \pm 1.38$ & $66-100$ & 40 \\
\hline Adult body weight (g) Male & $1839.5 \pm 22.274$ & $1650-2150$ & 217 \\
\hline Adult body weight (g) Female & $1388.75 \pm 10.961$ & $1250-1500$ & 256 \\
\hline Mortality (1-8 weeks) in \% & $6.92 \pm 1.43$ & $5-13$ & 962 \\
\hline Mortality (8-20 weeks) in \% & $5.47 \pm 1.22$ & $2-8$ & 652 \\
\hline Shank Length (cm) Male & $12.12 \pm 0.22$ & $7-17$ & 451 \\
\hline Shank Length (cm) Female & $9.78 \pm 0.24$ & $7-12$ & 451 \\
\hline Keel Length (cm) Male & $11.62 \pm 0.31$ & $8.5-15.5$ & 266 \\
\hline Keel Length (cm) Female & $09.82 \pm 0.42$ & $7.5-13.2$ & 365 \\
\hline
\end{tabular}

Table.3 Constraints faced by the farmers for rearing of local birds

\begin{tabular}{|l|c|}
\hline Name of the Constraints & Rank \\
\hline Disease outbreak and management & I \\
\hline Timely vaccination of the bird & II \\
\hline Inadequate grazing space & III \\
\hline Lack of regular deworming & IV \\
\hline Unavailability of veterinary services at village & V \\
\hline Infestation of external parasites & VI \\
\hline Availability of poultry feed (both in quality and quantity) & VII \\
\hline Problem of predators & VIII \\
\hline Theft of the bird & IX \\
\hline Poor production performance of local chickens & X \\
\hline Lack of housing & XI \\
\hline Lack of proper extension services & XII \\
\hline
\end{tabular}

Fig.2 Native Khadia Chicken Flock

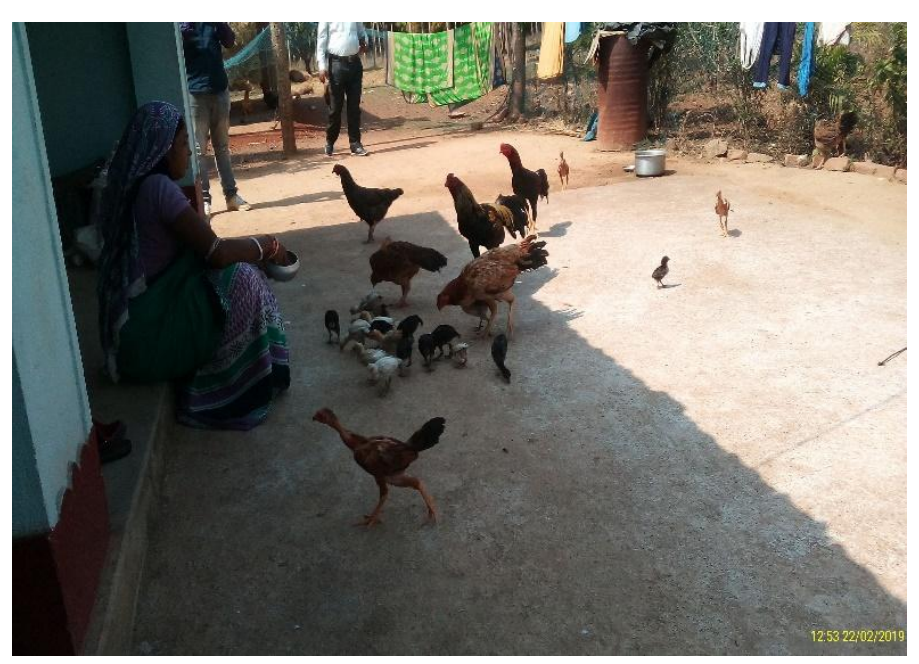


Fig.3 Brooding photo

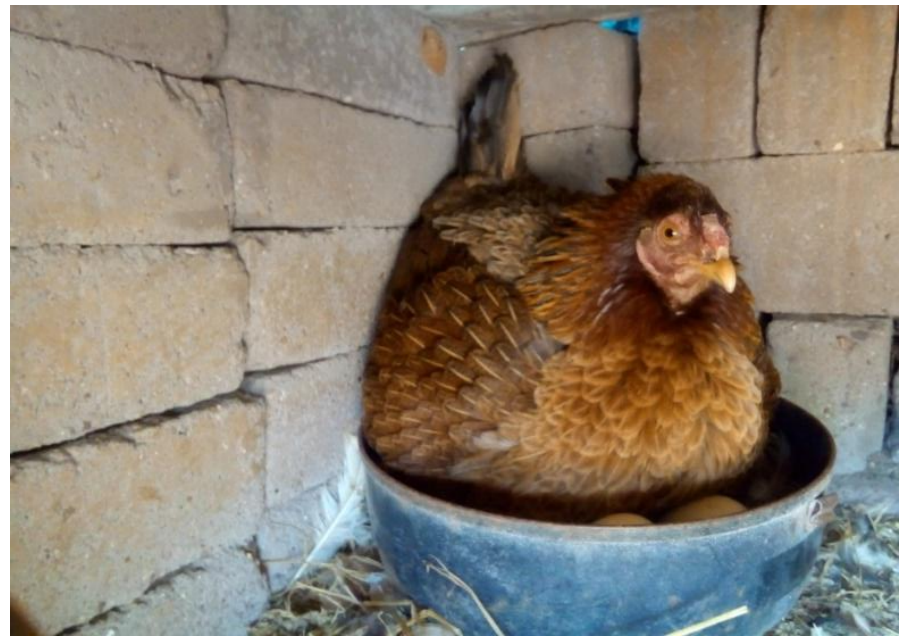

The shank length is very high in males (1.12 $\pm 0.22 \mathrm{~cm}$ ) whereas the females have the normal shank $(9.78 \pm 0.24 \mathrm{~cm})$ which is in line with Daikwo et al., (2011); Padhi et al., (2015); Reddy et al., (2015) and Das et al., (2016) who reported comparable shank length in females. The egg weight, adult body weight and shank length are better than the registered Hansli bird of Odisha (ICAR-NBAGR, 2018).

\section{Constraints of village chicken production system}

Diseases and inadequate supplies of vaccines and medicine were identified as the most prominent problems in both the districts. When farmers were asked about problems they experienced in rearing poultry, disease outbreak and management was ranked first followed by timely vaccination of bird as second most important constraints faced by the poultry farmers (Table 3 ). These types of problems are also reported by Rajendran and Balusamy (2018) and Alemayehu et al., (2018). The poultry rearers ranked inadequate grazing space, lack of regular deworming and unavailability of veterinary services at village as $3^{\text {rd }}, 4^{\text {th }}$ and $5^{\text {th }}$ respectively. The findings are almost in accordance with Alaol et al., (2015).
Village chickens play central role in supplying of high quality protein to the rural family foodbasket and providing cash income in addition to meeting the socio-religious obligation. The majority of the farmers included in this study expressed their willingness to increase their poultry activities, although the highest proportions of the farmers were low producers and most of them did not use vaccines to prevent diseases. The major problems in family poultry production included diseases, inadequate supply of vaccines and medicine, shortage of feed and lack of appropriate housing facilities. In order to increase the poultry production at the farmers' level, a systemic capacity building program on improved and scientific poultry farming should be organized specifically for rural women. Furthermore, preventive veterinary services may be made available to the native chicken farmers at their doorstep.

\section{Acknowledgement}

The authors are grateful to the Department of Science \& Technology, Government of Odisha, for funding the project to Odisha University of Agriculture \& Technology, Bhubaneswar, and Vice-Chancellor, OUAT, for providing necessary facilities to conduct 
the research. The support and cooperation extended by the respondents are also duly acknowledged.

\section{References}

Alaol, J. V., Khondakar R. G., Nihid, M, Imram N., Shamsur, B.2015. Evaluation of socio-economic condition and constraints of poultry farmers in selected areas of Bangladesh. African Journal of Poultry Farming. 3 (3): 8491.

Alemayehu, T., Bruno, J., Getachew, F. and Dessie, T. 2018. Socio-economic, marketing and gender aspects of village chicken production in the tropics: A review of literature. ILRI Project Report. Nairobi, Kenya: International Livestock Research Institute (ILRI).

Annual Report. 2018-19. ICAR-Directorate of Poultry Research, Rajendranagar, Hyderabad - 500 030, India

Bhuiyan, A.K.F.H., Bhuiyan,.M.S.A., Deb, G.K. 2005. Indigenous chicken genetic resources in Bangladesh: current status and future outlook. Anim. Genet. Resour., 36: 73-84.

Billah, S.M., Nargis, F., Hossain, M.E., Howlider, M.A.R., Lee, S.H. 2013. Family poultry production and consumption patterns in selected households of Bangladesh. J. Agric. Ext. Rural Dev., 5:62-69

Bogale, K. 2008. In situ characterization of local chicken ecotype for functional traits and production system in Fogera woreda, Amhara regional state. Msc Thesis. Submitted to the Department of Animal Science. Haramaya University. Ethiopia. pp.123

Chaka, H., Goutard, F., Bisschop, S.P., Thompson, P.N. 2012. Seroprevalence of Newcastle disease and other infectious diseases in backyard chickens at markets in Eastern Shewa zone, Ethiopia. Poultry Sci.91:862-869.
Daikwo, I.S., Okpe, A. A., Ocheja, J.O. 2011.Phenotypic Characterization of Local Chickens in Dekina, International Journal of Poultry Science 10 (6): 444447.

Dalal, D. S., Ratwan, P., Yadav, A. S. 2016. Genetic evaluation of growth, production and reproduction traits in Aseel and Kadaknath chickens in agroclimatic conditions of northern India, Biological Rhythm Research. ISSN: 0929-1016 (Print) 1744-4179 (Online) Journal homepage: https://www.tandfonline.com/loi/nbrr20

Das, A.K., Kumar, S., Mishra, A.K., Rahim, A. and Kokate, L.S. 2016. Evaluating body conformation and feed efficiency characteristics in CARI-Sonali grower chicken. Indian Journal of Animal Sciences86(2): 192-196.

Dereje, D. 2001. The effect of some common methods of storage and duration on egg quality and hatchability in East Wolegga, Ethiopia. M. Sc. Thesis Submitted to School of Graduate Studies Alemaya University. pp.83.

Eskindir, A., Kefelegn, K., Tadelle,D.. Banerjee, A. K. 2013. Phenotypic Characterization of Indigenous Chicken Population in Ethiopia. International Journal of Interdisciplinary and Multidisciplinary Studies. 1 (1) : 24-32.

FAO. 2003. Good practices in planning and management of integrated commercial poultry production in Southern Asia. FAO Animal Production and Health Paper, 159.

FAO. 2010. Poultry Meat and Eggs, agribusiness

handbook.www.eastagri.org. Accessed on $4 / 3 / 2012$.

Fisseha, M., Abera, M., Tadelle, D. 2010. Assessment of village chicken production system and evaluation of the productive and reproductive performance of local chicken ecotype in 
Bure district, North West Ethiopia, African Journal of Agricultural Research. 5(13): 1739-1748.

Hailemichael, N., Kefelegn, K.,Negassi, A. 2015. Phenotypic and Morphological Characterization of Indigenous Chicken Populations in Southern Zone of Tigray, Ethiopia. Journal of Biology, Agriculture and Healthcare, 5(21). www.iiste.org ISSN 2224-3208.

Halima, H., Neser, F. W. C., Marle-Koster, E. Van., De Kock, A. 2007. Villagebased indigenous chicken production system in north-west Ethiopia, Tropical Animal Health and Production

Haunshi, S., Doley, S., Shakuntala, I.2009. Production performance of indigenous chicken of north eastern region and improved varieties developed for backyard farming. Indian Journal of Animal Sciences 79 (9): 901-905.

Higenyi, J., Kabasa, J.D., Muyanja, C. 2014. Social and quality attributes influencing consumption of native poultry in eastern Uganda. Animal and Veterinary Sciences. 2(2): 42-48

Horst, P. 1988. Native fowl as reservoir for genomes and major genes with direct and indirect effects on production adaptability. Proceedings of the 18th World Poultry Congress, September 49, 1988, Nagoya, Japan, pp: 156-160.

Khandait, V.N., Gawande, S.H., Lohakare, A.C., Dhenge, S.A. 2011. Adoption level and constraints in backyard poultry rearing practices at Bhandara district of Maharashtra (India). Res. $J$. Agri. Sci., 2(1): 110 -113

Mohanta, N.B., Samal, L., Behura, N C., Pati, P.K., Bagh, J., Nandi, B.2018.Egg quality traits and meat composition of indigenous dwarf chicken of Odisha, Journal of Entomology and Zoology Studies, 6(2): 549-555.

Moussa, H.O., Keambou, T.C., Hima, K., Issa, S. Motsa'a, S.J. and Bakasso, Y.
2018. Indigenous Chicken production in Niger, Veterinary and Animal Science. doi:

https://doi.org/10.1016/j.vas.2018.11.00 1

Mulisa, D,D, Alemu, R,B, Keno, M,S, Furaso, A, Heidari, A, Chibsa, T,R,, Chunde, H.C. 2014. Characterization of Newcastle Disease Virus and poultryhandling practices in live poultry markets, Ethiopia. SpringerPlus3(1):1.

Nandi, B., Samal, L., Behura, N. C., Nayak, G. D., Das, D. P. 2017. Growth, efficiency and body conformation traits of Hansli breed of Odisha under intensive management system Journal of Entomology and Zoology Studies, 5(6): 2398-2408

Nigussie, H., Kebede, K., Ameha, N. 2015. Survey on Indigenous Chicken Production and Utilization Systems in Southern Zone of Tigray, Northern Ethiopia. Food Science and Quality Management.45. www.iiste.org ISSN 2224-6088 (Paper) ISSN 2225-0557 (Online).

Padhi, M.K., Chatterjee, R. N., Rajkumar, U., Bhattacharya, T.K., and Bhanja, S.K. 2015. Genetic and phenotypic parameters estimates for body weight, conformation, production and reproduction traits of PD1 (Vanaraja male line) during different periods. Indian Journal of Animal Sciences 85(8): $883-888$

Rajendran, B. and Balusamy, P,2018, Analysis on problems of poultry manufacturers and retailers in Namakkal district. International Journal of Applied Research, 4.

Reddy, M.V., Chinni Preetam, V., Reddy, A. R., Raj Kumar, U., Reddy, V. R., Gautham, K., Hareesh, D. and Guru Vishnu, P. 2015. Phenotypic Characterization of Indian Naked Neck Chicken Under Tropical Climatic 
Conditions. Asian Journal of Animal and Veterinary Advances, 10 (10): 527536

Saleem, F., Ahmad, B. H., Zahid, S., Kabeer, B(2014.Comparative Productive Performance of Indigenous naked neck and necked crossbred layer chickens, Pakistan J. Agric. Res. 27 (4).

Saleque, M.A. and Mustafa, S. 1996. Landless women and poultry: The BRAC model in Bangladesh. In: Integrated farming in human development, March 25-29, 1996, Greve, Denmark, pp. 38-55.

Selam, M. 2016. A review of poultry welfare in conventional production system, Livestock Research for Rural Development, 28 (12).

Shahjahan, Md, and Bhuiyan, A. K. F. H. 2016. Socio-economic condition and indigenous poultry production scenario in a selected cluster area of Bangladesh. Asian Australas. J. Biosci. Biotechnol., 1 (3): $557-563$

Sharma, R.K. 2007. Role and relevance of rural family poultry in developing countries with special reference to India. Family poultry, 17(1\&2): 35-40.

Singh, M.K., Kumar, S., Sharma, R.K., Singh, S.K., Singh, B., and Singh, D.V.2017. Assessment of pre and post-incubation parameters in Uttara breeder hens. Indian Journal of Animal Research51(5): 948-951.

Singh, M.K., Nayak, G.D., Sardar, K.K. 2016. Phenotypic characterization of native chicken populations reared under family-based free-range scavenging system in Odisha, India. Indian Journal of Animal Research. (50):839-845

SPSS (Statistical Procedures for Social Sciences) 2019.SPSS User's guide version 16.0.SPSS Institute Inc., Cary $\mathrm{NC}$.

Sultana, R., Nahar, N., Rimi, N.A., Azad, S., Islam, M.S., Gurley, E.S., Luby, S.P. 2012. Backyard poultry raising in Bangladesh: a valued resource for the villagers and a setting for zoonotic transmission of avian influenza. A qualitative study. Rural Remote Health, 12:1927.

Tadelle, D. 1996. Studies on village poultry production systems in the central highlands of Ethiopia. M.Sc Thesis, Swedish University of Agricultural sciences.

Tadelle, D., T. Million., Alemu, Y., Peters. K.J. 2003. Village chicken production systems in Ethiopia: Use patterns and performance evaluation and chicken products and socioeconomic functions of chicken. Livestock Research for Rural Development 15 (1).

Terefe, D., Redeat, B., Hassen, C., Melaku, S., Abebe, M., Getachew, G., Kumela, L., Delesa, D. 2015. Serological and molecular study of newcastle disease virus in village chickens in selected Rift-Valley Areas, Ethiopia. J. Vet. Sci Technol. 6:264.

\section{How to cite this article:}

Nayak, G. D., K. K. Sardar and Das, B. C. 2020. Socio-economic Condition of Khadia Poultry Farmers and Phenotypic Characteristics of Khadia Chickenof Northern Odisha, India. Int.J.Curr.Microbiol.App.Sci. 9(01): 1395-1404. doi: https://doi.org/10.20546/ijcmas.2020.901.154 